\title{
KI HAIAR DEWANTARA DAN KONSEP PENDIDIKANNYA DALAM PERSPEKTIF ISLAM
}

\author{
A. Masor Zt \\ Dosen Fakultas IAIN Sunan Gunung Djati Bandung
}

\begin{abstract}
Ki Hajar Dewantara is an outstanding Indonesian hero. He is a prominent political figure in the movement for independence and at the same time a cultural figure and an expert in journalism. He is the founding father in education and was successful in the formulation of the concept of national education. So far, nany people think that his concept of education is nationally-oriented at best. The fact is that some of his concepts in education had been inspired by Islamic educational principles. Any study on Ki Hajar Dewantara and his concepts of education seen from the point of view of Islamic doctrines should be carefully conducted so as to avoid any misunderstanding and misinterpretation. This article, which is an abstract and modification fron the writer's dissertation, used Islamic point of view to study Ki Hajar Dewantara and his notion of education. In great details, the article studied the phenomena of $\mathrm{Ki}$ Hajar Dewantara in relation to Islamic doctrines, his concepts of education seen from Islamic education perspectives, his view on religious education and his view on the relevancy between his moral education and Islamic moral and character education.
\end{abstract}

\section{A. Pendahuluan}

Ki Hajar Dewantara cukup populer bagi bangsa Indonesia terutama di kalangan pendidik. Ia dikenal sebagai Bapak Pendidikan Nasional. Ia telah menampilkan hasil pemikirannya tentang konsep pendidikan nasional yang diimplemen- tasikan melalui sebuah lembaga perguruan Taman Siswa.

Selama ini banyak orang memahami bahwa konsep pendidikan Ki Hajar Dewantara hanya nasional an sich, padahal banyak prinsip prinsip pendidikan Islam menjiwai konsepsinya. Hal ini dapat dibandingkan dengan kon- 
sep pendidikan Muh. Iqbal atau Ali Mubarok. ${ }^{1}$ Oleh karena itu, penelitian terhadap figur $\mathrm{Ki}$ Hajar Dewantara dan konsep pendidikannya ditinjau dari segi ajaran Islam merupakan hal yang perlu dilakukan, terutama bagi pemikiran pengembangan pendidikan Islam yang kondusif dengan alam Indonesia.

Ki Hajar Dewantara adalah tokoh yang berjiwa nasional, ia muslim yang taat. Tentu ia tidak melepaskan pikirannya dari upaya untuk mencetuskan konsep yang layak dan sejalan atau sekurang kurangnya sejalan dengan prinsip prinsip pendidikan Islam. Ia mengetahui bahwa waktu itu bangsa Indonesia lebih dari $95 \%$ beragama Islam.

Penelitian berkenaan dengan Ki Hajar Dewantara dan pendidikannya dipandang dari segi ajaran Islam memerlukan sikap hati-hati agar tidak menimbulkan kesalah fahaman dalam penafsiran. Akan tetapi, saya mempunyai kecenderungan bahwa ia sebagai tokoh pendidikan yang beragama Islam, tentu konsepnya yang bersifat umum itu telah dipertimbangkan dari berbagai aspek termasuk agama Islam, agar tidak bertentangan dengan ajaran yang dianut oleh mayoritas bangsa.
Tulisan ini, yang merupakan ringkasan dan modifikasi dari disertasi, mengangkat pandangan Islam mengenai Ki Hajar Dewantara dan gagasan-gagasannya tentang pendidikan. Secara rinci tulisan ini mengangkat keberadaan Ki Hajar Dewantara dalam kaitannya dengan ajaran Islam; keberadaan konsep pendidikan Ki Hajar Dewantara ditinjau dari segi pendidikan Islam; bagaimana pendidikan (pengajaran) agama menurut pandangan Ki Hajar Dewantara, dan bagaimana relevansi pendidikan budi pekerti dengan pendidikan akhlak dalam Islam.

\section{B. Konsep Pendidikan Ki Hajar Dewantara}

Sebagai tokoh pendidikan, Ki Hajar Dewantara berjuang untuk dapat menjawab pertanyaan, "pendidikan apa dan yang bagaimanakah yang dipandang paling cocok untuk anak anak bangsa Indonesia." Jawaban yang dipandangnya tepat adalah pendidikan nasional yaitu pendidikan yang harus dilaksanakan berdasarkan semangat dan jiwa kebangsaan. Jiwa merdeka dan kerakyatan untuk menghadapi kolonialisme dan membuang feodalisme. Ia menekankan agar "manusia mer-

'Muhammad Iqbal menolak pendidikan Asing dan ingin sekali meningkatkan pendidikan yang dihasilkan oleh sejarah dan kebudayaan sendiri. Lihat Kurshid Ahmad, Principle of Islamic Education (Prinsip-prinsip Pendidikan Is/am), terj. As. Robith, Progressif, Surabaya, 1992, hlm 19. 
deka lahir batin, hidup salam dan bahagia untuk membangun masyarakat tertib dan damai". Landasan ini ia pakai sebagai landasan pergerakan rakyat. Konsep pendidikan nasional Ki Hajar, secara tidak langsung terangkum dalam rumusan pidato pada waktu pembukaan Taman Siswa (3 Juli 1922 ) yaitu :

- Pendidikan dan pengajaran agar dapat tumbuh sehat lahir batin;

- Pengajaran yang kita terima dari orang Barat tidak terlepas dari pengaruh kolonialnya, yakni kita dididik untuk keperluan yang mendidik;

- Keadaan ini tidak lenyap bila hanya dilawan dengan pergerakan politik, tetapi harus juga mengutamakan penyebaran pendidikan nasional;

- Pelaksanakan pendidikan/ pengajaran nasional harus ada kemerdekaan;

- Pengajaran harus tersebar di kalangan rakyat banyak.

Pemikiran di atas, merupakan titik tolak Ki Hajar untuk menyelenggarakan pendidikan nasionalnya. Titik tekannya berakar dan berorientasi pada kebudayaan sendiri. Selain itu, ia menyodorkan pendidikan budi pekerti yang dipandang penting bahkan wajib diajarkan. Ada empat tahapan yang harus diperhatikan, yaitu : syari'at, hakikat, tarikat, sampai makrifat (Ki Hajar, Karya...1977 : 485 490). Sumber pelajarannya yaitu cerita, legenda, lakon sandiwara, sejarah, cerita kepahlawanan, kitab suci agama, dan adat istiadat. Selanjutnya, diteruskan dengan pendidikan adab, sebagai media membentuk bangsa yang berperadaban sehingga memiliki keluhuran budi, kesucian jiwa, dan kemuliaan.

Ki Hajar telah merumuskan asas pendidikan dan pengajaran serta tujuannya. Pada awalnya asasasas pendidikannya itu terdiri dari tujuh pasal, namun tahun 1947 dilakukan upaya penyusunan/ perumusan kalimat yang padat dan simpel. Karena itu, pada tahun 1950 ditetapkan Pancadarma (sebutan asasnya) yaitu kemerdekaan, kodrat alam, kebudayaan, kebangsaan, dan kemanusiaan. Adapun tujuan pendidikan dalam konsep Ki Hajar adalah "menuntun segala kekuatan kodrat yang ada pada anak anak itu agar mereka sebagai manusia dan anggota masyarakat dapatlah mencapai keselamatan dan kebahagiaan setinggi-tingginya" (Ki Hajar, Karya ... 1977 : 20).

Berkaitan dengan komponen proses pendidikan, menurut $\mathrm{Ki}$ Hajar, paling tidak harus mencakup pendidik, anak didik, materi pelajaran, metode mengajar, dan lingkungan pendidikan. Menurutnya, pendidik adalah pamong yang bertanggung jawab langsung guna tercapainya tujuan pendidikan. 
Konsekuensinya guru harus menguasai teori mengajar dan belajar, ilmu jiwa anak, pengembangan sistem pengajaran dan mampu melakukan evaluasi. Oleh karena itu, ia menekankan agar diadakan latihan dan pendidikan bagi guru yang sudah ada dan mendirikan sekolah khusus calon guru agar kompeten dan profesional.

Anak didik menurutnya sasaran yang harus diayomi karena memiliki kodrat yang harus dituntun, dibimbing, dan dikembangkan agar ia mencapai keselamatan dan kebahagiaan hidup. Anak dilahirkan sama (menurut fitrahNya), lalu orang mendidik dengan watak dan cara yang berbeda. $\mathrm{Ki}$ Hajar juga membagi tahapan perkembangan anak, yaitu waktu I : 17 tahun (kinder periode), waktu II: 714 tahun (intellectuele periode) dan masa III : 1421 tahun masa dewasa. Pentingnva pembagian ini, untuk menyesuaikan materi, metoda dan hal lain yang dibutuhkan.

Materi pelajaran menurut $\mathrm{Ki}$ Hajar diwujudkan dalam berbagai bentuk pelajaran dan dirumuskan inti serta uraian pelajaran dari sumber tertentu untuk pegangan guru. Bahan pelajaran disesuaikan tingkatan/kebutuhan anak sebagai individu, keluarga, masyarakat, dan bangsa. Jadi menurutnya, pelajaran itu memberikan pengetahuan/keterapilan yang berpengaruh terhadap lahir batinnya anak, untuk bekal kehidupan dalam pergaulan dan pengabdiannya kepada yang lebih luas dan tinggi.

Metoda mengajar yang dikembangkan oleh Ki Hajar Dewantara adalah memberi kebebasan pada anak didik untuk dapat berkembang sejalan dengan kodratnya, yang dikenal dengan among system atas dasar trilogi kepemimpinan, yaitu Ing ngarso sung tulodo, Ing madyo mangun karso, dan Tut Wuri Handayani. Ia telah mengungkapkan bahwa cara-cara (mendidik) itu amat banyak, tetapi secara pokok dapat dibagi kepada enam hal, yaitu : memberi contoh (voorbeld), pembiasaan (pakulinan, gewoontevorming), pengajaran (leering, wulang wuruk), perintah, paksaan, hukuman, (regering en tucht), laku (zeftbeheersching, zelf dicipline), dan pengalaman lahir batin (nglakoni, ngerasa, beleving).

Lingkungan pendidikan sangat penting terciptanya situasi yang kondusif bagi pembinaan dan perkembangan anak didik. Lingkungan itu ia sebut dengan "trisentra pendidikan," yaitu keluarga, perguruan sekolah, dan alam pemuda (masyarakat). Ketiga pusat pendidikan tersebut mempunyai tugas masing masing, yaitu : alam keluarga merupakan pusat pendidikan pertama dan terpenting. Tugasnya mendidik budi pekerti dan laku sosial; alam perguruan pusat pendidikan yang mengusahakan kecerdasan pikiran dan ilmu pengetahuan; dan alam pe- 
muda (masyarakat) membantu kepada kecerdasan jiwa maupun budi pekerti.

Beberapa hal yang sangat esensi sehubungan dengan prinsip pendidikannya antara lain yaitu kodrat alam (petunjuk bagi hidup manusia), kemanusiaan (memperhatikannya secara totalitas), Kebangsaan (manusia mempunyai kebiasaan hidup yang berbeda maka berbeda pula cara pendidikannya), bebas dan merdeka (untuk menentukan nasibnya). Hal itu berprinsip kepada trikon yaitu konsentris, konvergen dan kontinu. Lima macam yang secara spesifik lebih menunjukkan sebagai strategi $\mathrm{Ki}$ Hajar Dewantara dalam menyukseskan konsep pendidikannya, yaitu menarik simpati masyarakat, mobilisasi nasional tentara damai (pendidikan), mendorong berkembangnya partikelir, mencanangkan wajib belajar memberantas buta huruf, menjalin hubungan dalam dan luar negeri.

Untuk merealisasikan konsep dan semua ide-idenya tentang pendidikan yang bersifat kultural, nasional, dan sosial, maka tanggal 3 Juli 1922 Ki Hajar mendirikan lembaga perguruan kebangsaan yang bernama Taman Siswa.

\section{Ki Hajar Dewantara dan Konsep Pendidikannya dalam Perspektif Islam}

\section{(1) Ki Hajar Dewantara dan Ajaran Agama Islam}

Aspek keimanan. Dalam aspek keimanan terutama menyangkut keyakinannya berkenaan rukun iman, diketahui bahwa Ki Hajar Dewantara telah terpatri keimanannya sejak kecil dengan dasardasar akidah islamiyah, berkat keluarga dan lingkungannya yang islami. Ia menerima bimbingan/ ajaran dari ayahnya soal iman dan telah mengetahui serta biasa mengucapkan syahadat. Begitu yakinnya terhadap Tuhan, ia menyatakan "Sujudlah ke hadirat Tuhan karena hanya Tuhanlah yang suka mendengarkan suara hatimu dan akan memberi keadilan padamu." 2 Lebih tegas lagi soal keyakinannya seperti di dalam ucapan "harus tawakkal hanya kepada Allah", ia menyimpulkan "Dengan ini kita sudah maju begitu jauh, hingga akan jelas dan terang bagi kita sebab satu juru pengatur hidup tanpa ada yang kedua, memegang seluruh pimpinan untuk selamanya. ${ }^{\prime 3}$

${ }^{2}$ Ki Hajar Dewantara, Karya Bagian I Pendidikan, Majlis Luhur Taman Siswa, Yogyakarta, 1977, hlm.10. Seperti termuat dalam suratnya tanggal 15 Sepetember 1912 yang ditulis di kapal Bulow di Teluk Benggala dalam perjalanannya menuju tempat pembuangan (Belanda)

${ }^{3}$ Ki Hajar Dewantara, Karya .......hlm.10. 
Dari pernyataannya itu, tampak bahwa ia hanya mengakui adanya satu Tuhan (Allah). Di dalam 10 fatwa sendi hidup merdeka dikatakan bahwa segala kekuatan/ kekuasaan yang mengelilingi hidup itu adalah kekuasaan Tuhan. Pada nomor 9 ia mengatakan bahwa kita harus "ngandel," percaya, yakin kepada kekuasaan Tuhan. ${ }^{4}$ Ia sering berucap de mensch wikt, god beschikt (Manusia wajib berikhtiar tetapi Tuhanlah yang menentukan). Menurutnya, "manusia berkuasa untuk berpikir, memilih, berbuat menurut kehendaknya sendiri, tetapi di belakang itu wajiblah ia berkeyakinan ada satu juru pengatur yang dapat membatalkan segala sikap kita karena kekuatan yang tidak kita ketahui" (Ki Hajar, Buku I Pendidikan, 1977: 127).

Ia mengakui dan menyatakan báhwa "sebagai yang beriman kepada Tuhan, saya sangat takut apabila sampai dijauhi oleh Tuhan". Pada beberapa kesempatan tertentu ia juga mengungkapkan dan meyakini sifat sifat Allah sebagai penentu, maha kuasa, maha pengatur, maha kuat tak terbatas, maha adil, maha mendengar, maha pencipta, maha tertib, maha sempurna dan Allah sebagai rabbul 'alamin (Tauchid, perjuangan..., 1973: 54 57). Dari ungkapan yang berupa pengakuan, persaksian pernyataan, dan ajakan kepada orang lain, maka keimanan Ki Hajar Dewantara terhadap Allah jelas memiliki kadar yang berarti bagi layaknya seorang mukmin.

Pengucapan syahadat mencakup pula pengakuan keimanan kepada rasul Allah. Ia telah mempelajari dan membandingkan berbagai agama dan ajarannya. Menurutnya, agama itu pengajaran yang pada tingkat pertama mengajarkan adanya Tuhan yang maha kuasa, yang mengatur dengan sempurna segala yang ada, yang menetapkan adanya hidup kekal sesudahnva hidup di dunia ini. Pada tahap kedua semua agama mengajarkan kewajiban manusia terhadap hidup lahir dan batin kemudian adanya bentukan/stelsel tertentu sehingga timbul peraturan-peraturan khusus yang membedakan antara agama yang satu dengan yang lain. Dari rangkaian kalimat tersebut; jelas ia telah mendalami berbagai agama dan rasul pembawa ajarannya yang menyatakan kebenaran Islam.

Sejak kanak-kanak, ia telah belajar agama (Islam). Ia suka mengaji bahkan suka tiduran di masjid dekat rumahnya, menghapal (di luar kepala) ayat-ayat Alquran; ia mengatakan bahwa "salah satu dari sekian banyak firman yang harus kuhapalkan di luar kepala waktu aku masih kanak-kanak dulu ialah wa an laisa

${ }^{4}$ Ki Moch. Tauhid, Perjuangan dan Ajaran Hidup Ki Hajar Dewantara, Majlis Luhur Taman Siswa, Yogyakarta, 1963, hlm. 56. 
li al-insani illa maa sa'a, artinya ialah manusia sungguh tidak akan mendapatkan kecuali yang diusahakannya (QS al Najm: 39).

Dalam beberapa hal banyak pernyataan-peryataannya yang relevan dengan ayat-ayat Alquran. Ia pernah mengajak/menyeru untuk takwa kepada Allah sesuai dengan ajaran Islam. Ia mengatakan, "manusia hendaknya, berpegang teguh kepada patokanpatokan ilahi (naqli) dan hasil hadis nabi-Nya, kemudian manusia menggunakan akal dengan membaca alam di sekelilingnya untuk membuktikan kebenaran yang ditegaskan oleh naqli (Ki Hajar, 30 Tahun Taman Siswa, hlm. 352). Oleh karena itu, ia termasuk sebagai yang mengimani kitab Allah dan juga mengimani Qada dan Qadar. Hal ini terbukti dari banyaknya perilaku penyerahan diri kepada Allah setelah ia berusaha keras akan segala sesuatu yang diharapkannya. Ia mengimani akan adanya yaumil akhir sebagaimana mengatakan "yah, kiamat pasti datang, pokoknya itu urusan Tuhan bukan". Ia juga mempercayai adanya hidup sesudah mati, hari kini dan hari akhirat. Ia pernah berkata "hidup di dunia itu hanya sebentar, sedang di akhirat adalah kekal. Mati adalah awal kehidupan" (Tauchid, Perjuangan..., 1973 : 54).

Berdasarkan data, ia dapat dipandang memiliki keimanan yang kuat, mendalam dan se- bagiannya berdasarkan kepada ayat Alquran dan hadis Nabi, memenuhi kapasitas pengucapan, pengamalan, dan kekukuhan keyakinan di dalam hatinya.

Aspek Peribadatan. Dalam masalah peribadatan semasa hidupnya Ki Hajar termasuk seorang muslim yang taat melakukan peribadatan, baik yang mahdah maupun yang gair mahdah. Secara rutin ia lakukan salat fardu, bahkan juga telah terbiasa melakukan salat salat sunat. Dalam keadaan tertentu, ia melakukan sujud (syukur) kepada Allah. Karena jengkelnya atas penjajah, ia sering berucap syukur alhamdulillah aku bukan seorang Belanda. Salat Jumat baginya sudah terbiasa berada di deratan saf depan, sejak kecil suka dibawa ayahnva duduk di depan dengan para sesepuh/ulama.

Ia juga taat dalam membayar zakat. Lebih dari itu, ia mengagumi konsep ajaran Islam tentang infak, sedekah, dan jariah yang menitikberatkan nilai nilai sosial terhadap sesama muslim (Ki Hajar, Kebudayaan, 1967 : 53 54). Dalam hal saum (berpuasa), sudah sejak kecil ia terlatih. Menurutnya, puasa itu membersihkan lahir dan batin dari kotoran dan dosa. Ia banyak melakukan mati geni dan poso sunnah, namun sayangya ia tidak sempat melakukan ibadah haji sebagai rukun Islam yang kelima.

Hal ini menunjukkan dirinya sebagai hamba Tuhan sebab pernyataan tersebut jelas melambang- 
kan dasar kehidupan yang agamis. Semua itu, menurutnya, harus disertai ilmu, semboyannya adalah "lawan sastra ngerti mulya" yang berarti dengan pengetahuan menuju kepada kemuliaan, dan ini sejalan dengan yang dimaksud oleh Firman Allah dalam Alquran surat al-Mujadalah. Ki Hajar juga menegaskan bahwa amalan seseorang itu harus dengan ilmu dan ilmu itu harus diamalkan. Menurutnya: "ngelmu tanpa laku kotong, laku tanpa elmu cupet, ilmu tanpa amal seperti pohon kayu yang tidak berbuah".

Aspek Akhlak. Dalam masalah akhlaq telah diketahui bahwa Ki Hajar Dewantara adalah pencetus konsep pendidikan Budi Pekerti dan pada awal kemerdekaan telah direalisasikan di sekolah sekolah formal pemerintah seperti S.R., S.M.P., S.T. dan sebagainya. Di dalam konsepnya dinamakan juga. pendidikan adab yang merupakan pendidikan moral atau pendidikan akhlaq di dalam ajaran Islam; dan menurutnya materi pendidikan budi pekerti itu adalah religi (agama). Di sini nampak bahwa ia memahami dan memiliki pengetahuan tentang materi akhlaq, baik yang mahmudah maupun yang madzmumah.
Ki Hajar Dewantara berlatar belakang keturunan dari keluarga yang agamis. Ia berdarah Dipenogoro, berdarah Madura berdarah kesultanan, yang notabene Islam dan berdarah Sunan Kalijogo (Ulama terkenal) dari salah seorang wali songo. Ia menyenangi keagamaan yang islamis dan filosofis, bahkan banyak menampilkan syair syair dan petuah petuah yang islami. pada waktu hidupnya, ia erat bergaul dengan banyak tokoh tokoh Islam, baik cendekiawan maupun ulama. ${ }^{5}$ Jika dipermasalahkan sampai sejauh mana jiwa keagamaan yang dimilikinya berpengaruh terhadap keluarga dan masyarakat tidak ditemukan data kongkrit yang tektual. Akan tetapi dari pendekatan wawancara, ternyata keluarganya beragama Islam.

\section{(2) Kajian mengenai konsep.}

Konsep Pendidikan Nasional. Konsep Pendidikan Nasional adalah pendidikan kebangsaan, pendidikan untuk kemajuan bangsa, mencerdaskan dan mensejahterakan bangsa. Istilah nasional bukan monopoli suatu golongan/ kelompok organisasi tertentu. Pendidikan Nasional seperti yang diharapkannya pendidikan yang menekankan jiwa kebangsaan dalam arti cinta nusa (tanah air),

${ }^{5}$ Dari kalangan cendekiawan a.I. : Dr. Soekiman Wiryosanjoyo (tokoh Masyumi), H.A.R Baswedan (budayawan muslim Masyumi), dari kalangan ulama a.I: KH. Achmad Dachlan. K.H.O.S Tjokroaminoto, KH Wahid Hasyim, dan empat serangkai yang jadi dua seirama adalah KH. Mas Mansur. 
bangsa (sesama), budaya (termasuk norma kehidupan beragarna).

Terapan konsep pendidikan nasional masuk dalam Undang Undang Dasar Rl. Demikian juga masuk kedalam pokok pikiran pembaharuan pendidikan nasional hasil kerja komite pembaharuan nasional tahun 1979 dan kemudian masih tetap menjadi dasar dalam mempertimbangkan sebuah sistem yang mapan sehingga lahirnya Undang Undang tentang sistem pendidikan nasional 1989.

Konsep pendidikan nasional secara spesifik dilahirkan dengan motiviasi dan orientasi nasional (kebangsaan) dalam upaya membebaskan eksploitasi dari sistem pendidikan penjajah dan dalam rangka mengangkat harkat martabat bangsa agar sederajat dengan bangsa bangsa lain di dunia. Konsep ini ingin membangun manusia Indonesia baru, menyiapkan tenaga pejuang kemerdekaan, pembela kemanusiaan yang bersemangat kebangsaan. Menelaah hal tersebut dari ajaran agama Islam, sebenarnya bagi bangsa Indonesia tidak masalah, karena rakyatnya mayoritas beragama Islam. Pendidikan Nasional yang beralaskan garis hidup bangsanya, jika dikaitkan dengan agama, jelas garis hidup yang islami. Kata mengangkat derajat negara dan rakyatnya pun otomatis cita cita Islam agar terwujud baldah thoyvibah wa rabbun ghafur. Sedang mengenai bekerjasama dengan bangsa lain sepanjang tidak mengeksploitasi dan memusuhi Islam, dianjurkan Allah seperti terkandung dalam kalimat "syu'uban lita'arafu" dan rahmatan lil "alamin."

Konsep tentang Masyarakat dan Budaya. Permasalahan utama pendidikan adalah manusia baik sebagai individu maupun sebagai makhluk sosial, karena umumya pendidikan tidak akan terjadi apabila tidak ada terdidik dan pendidik. Keduanya mempunyai kepentingan terjadinya proses pendidikan. Oleh karena. itu, cukup beralasan apabila. memandang pendidikan dari dua kepentingan, yaitu untuk kepentingan individu dan masyarakat.

Setiap usaha perumusan pendidikan dan tujuan pendidikan menurut Ki Hajar Dewantara harus diselaraskan dengan kehidupan masyarakat di tempat pendidikan itu dilaksanakan, baik dengan falsafah yang dianut maupun dengan kondisi politik serta sosial budayanya. Hal tersebut dimaksudkan agar pendidikan itu dalam prosesnya, kondisional dengan tuntutan dan kehidupan masvarakatnya.

Konsep Pendidikan Budi Pekerti. Ki Hajar Dewantara menyatakan bahwa manusia sebagai titah Tuhan terdiri dari badan wadag dan badan halus, jasmani dan rohani. Mengingat kodrat iradatnya Tuhan, tiada selayaknya bila usaha kita cuma mementingkan salah satu dari dua 
bagian yang tak dapat dipisahkan itu. Oleh karena itu anak perlu diberikan pula pendidikan budi pekerti. Menurutnya secara definitif budi pekerti itu sebagai perilaku atau perbuatan manusia yang berdasarkan kodratnya mengandung nilai-nilai kemanusiaan. Hal itu muncul dari bersatunya gerak, pikiran, perasaan dan kemauan yang kemudian menimbulkan tenaga. (Ki Hajar, 30 Tahun...., $1952: 25$ ). Pada tiap tiap bangsa, filsafat semacam itu ada. Oleh karena itu faham seperti (mores, etika. sanyasa, miamsa, zen dan sebagainya) dapat diindahkan oleh semua agama, yang pada dasarnya menghendaki hidup dalam kebaikan dan terlepas dari keburukan. Perbedaan yang esensi, menyangkut niat awal dan tujuan akhir, cara-cara melakukan dan sumber ajarannya. Moral selalu berkaitan dengan tata-nilai. Menilai berarti menimbang dengan ukuran, dan yang dinilai adalah prilaku atau aktivitas manusia. Hasilnya dapat berupa bermanfaat atau tidak (merusak), baik atau buruk, benar atau salah dan dapat pula religius atau tidak.

Budi pekerti menurut Ki Hajar Dewantara adalah perilaku yang baik menurut sifat dan kodratnya menuju ke arah perbuatan yang umum. Ia menyatakan: "Menganjurkan atau memerintahkan anak untuk duduk yang baik, jangan berteriak-teriak agar tidak menganggu anak yang lain, bersih badan dan pakaiannya, hormat terhadap guru, ibu bapak dan orang tua lainnya, menolong teman teman yang perlu ditolong sedemikian seterusnya, itu semua sudah merupakan pengajaran budi pekerti"(Ki Hajar, Karya.... 1977 : 485). Walaupun pemberian contohnya sangat sederhana, proses dan tujuan akhirnya menunjukkan kemuliaan hidup yang beradab. Anak didik diharapkan memiliki etika hidup yang baik yang bukan saja akan memberikan nilai positif pada dirinya akan tetapi juga akan menjamin ketentraman dan keamanan bagi orang yang ada di sekelilingnya. Hal ini sesuai dengan ajaran Islam. Ki Hajar Dewantara mengaku memang pelajaran ini bersumber dari agama. Memperhatikan tahapan tahapan yang diajarkan yaitu: syari'at, hakikat, tarikat dan marifat. Demikan juga adab sebagai sasaran beriknya maka jelas hal itu relevan dengan pendidikan akhlak dalam Islam karena Islam sangat memperhatikan masalah pendidikan akhlak (Alquran surat Al-Qalam : 4).

\section{(3) Kajian tentang Azas dan Tujuan Pendidikan.}

Azas Pendidikan. Sejak berdirinya Taman Siswa Tahun 1922 Ki Hajar Dewantara telah merumuskan azas azas pendidikan kepada tujuh pasal (Ki Hajar, Karya ..., 1977 : 69). Pada tahun 1950 azas azas pendidikan dari hasil pe- 
mikiran Ki Hajar Dewantara itu terangkum dan ditetapkan dalam 'Pancadarma' yang terdiri dari lima dasar, yaitu: (1) Kemerdekaan; (2) Kodrat Alam; (3) Kebudayaan, (4) Kebangsaan, dan (5) Kemanusiaan. Perubahan itu adalah hasil rumusan Panitia yang sengaja dibentuk untuk itu. $\mathrm{Na}$ mun tidak menghilangkan jiwa dari ketujuh pasal tadi. Azas-azas tersebut tidak bertentangan dengan ajaran Islam tetapi Islam sebagai dasar lebih lengkap dan mineral karena Islam itu sebagai ciptaan Allah.

Tujuan Pendidikan. Dihubungkan dengan pendidikan Islam, tujuannya memberikan gambaran yang senada bahwa tujuan pendidikan itu dalam prosesnya harus selaras dengan kodrat manusia. Implikasinya, perumusan tujuan pendidikan harus disesuaikan dengan kondisi psikis anak didik, ${ }^{6}$ agar bimbingan itu dapat dilaksanakan secara efektif dan lingkungan belajar siswa harus pula mencerminkan kondisi edukatif untuk merangsang tumbuhnya kodrat secara optimal, sehingga proses menginternalisasikan nilainilai ajaran Islam itu dapat memberikan kemampuan fungsional bagi kehidupan masyarakat. Dalam pandangan Islam individu manusia itu dapat mencerminkan manusia yang berkualitas dan berkepribadian islami. Bagi masyarakat, proses pendidikan akan memberikan sumbangan pada kontinuitas dan pembudayaan ajaran Islam. Oleh karena itu individu sebagai hasil proses pendidikan diharapkan dapat merealiasasikan apa yang dikembangkan melalui pendidikan dan pengajaran, sehingga akan tercapainya upaya perwujudan keserasian hidup manusia yang bersifat manusiawi seperti dikonsepkan Ki Hajar Dewantara.

Memang terdapat kesenjangan di dalam susunan kata kata dari rumusan tujuan ini apabila dikaitkan dengan tujuan akhir pendidikan. Pendidikan Islam mengharapkan agar menjadi insan (hamba) yang beribadah kepada Allah. Sedangkan rumusan Ki Hajar Dewantara ialah agar mencapai keselamatan dan kebahagiaan setingi tingginya. Namun jika diamati secara cermat, penafsiran penulis menjadi keselamatan yang tinggi, keselamatan bukan hanya di dunia saja (yang di pandang sementara) tapi juga di akhirat (yang dipandang kekal). Hal tersebut didukung oleh firman Allah dalam Alquran surat Ali Imran : 102. Bahagia menurutnya bukan bahagia dunia saja yang ia pandang sementara tapi juga kebahagiaan akhirat yang tinggi/ langgeng lebih dari kebahagiaan ${ }^{6} \mathrm{Da} a$
akalnya 
dunia. Kesimpulannya jika dilihat sepintas (tekstual), sejalan dengan sasaran antara pendidikan Islam, jika dihayati cermat (kontekstual), maka bisa diprediksi tidak bertentangan dan dapat sejalan dengan tujuan akhir pendidikan Islam.

\section{(4) Kajian Berkenaan dengan Proses Pendidikan}

Pendidikan merupakan suatu proses yang dilaksanakan untuk mencapai tujuannya. Pencapaian tujuan itu secara operasional dilaksanakan melalui proses belajar mengajar. Inti dari proses pendidikan terletak pada interaksi antara siswa belajar dan guru mengajar. Proses belajar mengajar merupakan segala upaya yang dilaksanakan agar dapat terarah pada tujuan sesuai program belajar. Untuk itu terdapat beberapa komponen yang harus menjadi pusat perhatian.

Pendidik. Pendidik artinya orang yang melakukan kegiatan mendidik. Tugasnya adalah mendidik sesuai dengan tujuan pendidikan yang ditetapkan. Apabila Ki Hajar Dewantara mengartikan pendidikan sebagai suatu tuntunan di dalam hidup tumbuhnya anakanak, maka tugas pendidik itu menurutnya adalah menuntun tumbuh kembangnya kodrat anak didik (Ki Hajar, Karya ..., 1977 : 20). Konsekuensinya, segala cara, metode, alat yang digunakan oleh pendidik untuk mendidik harus mencerminkan suatu perbuatan menuntun.

Ki Hajar menganalogikan tugas seorang pendidik dengan seorang petani yang hanya dapat menuntun tumbuhnya padi, ia dapat memperbaiki dan menumbuhsuburkan tanaman itu; tetapi ia tidak dapat mengganti kodrat irodatnya padi (Ki Hajar, Karya .... 1977 : 21). Seorang guru (pendidik) dalam melaksanakan tuntunannya tidak boleh otoriter dalam arti menggunakan paksaan-paksaan. Kemajuan yang sejati hanya dapat diperoleh dengan perkembangan kodrati yang dikenal dengan evolusi (Ki Hajar, Taman Siswa... 1981 :55). Dari dasar kodrat inilah, yang kemudian memunculkan sistem among dan guru yang berprestasi sebagai pamong. Dalam sistem ini berpegang kepada semboyan "Ing ngarso sung tulodo, ing madya mangun karso, Tut Wuri Handayan", mengawasi, membimbing guna memberikan kesempatan kepada anak didik untuk berjalan dan berupaya mengembangkan kreatifitasnya. Rol yang dimainkan pamong adalah mengantisipasi secara aktif serta menyingkirkan segala penyakit yang merintangi perkembangan kodrat anak. Oleh karena itu guru harus profesional, memiliki kompetensi dan mampu meneliti dasar siswa secara individual agar keadaan bimbingan kondusif dengan dasar dasar yang tersedia pada anak itu. 
Pemikiran tersebut apabila ditinjau dari segi pendidikan Islam, setidaknya memberikan suatu gambaran tentang posisi guru yang ideal. Di sini perlu dipikirkan suatu pendekatan mengajar yang dapat menempatkan guru sebagai pamong serta dipandang dapat mengembangkan kodrat anak didik secara optimal. Baik dalam aspek afektif, kognitif maupun psikomotor. Jadi bukan hanya mahir secara teori, akan tetapi secara praktis dapat juga memposisikan siswa sebagai subjek belajar. Hal yang penting adalah bagaimana, mengaktualisasikan pandangan yang menyatakan mengajar adalah aktivitas guru dalam mengajar siswa belajar. Pada posisi ini, sudah diakui para ahli pendidikan Islam bahwa guru berada pada tugas yang berat namun mulia.

Anak didik. Ki Hajar Dewantara memandang pendidikan sebagai upaya untuk memajukan pertumbuhan budi pekerti (kekuatan, batin, karakter) fikiran dan tubuh anak agar dapat memajukannya ke arah kesempurnaan hidup, yakni penghidupan dan kehidupan anak anak yang kita didik selaras dengan dunianya (Ki Hajar, Karya...., 1977 : 14). Pengertian tersebut, dihubungkan dengan kepentingan suatu bangsa, maka pendidikan akan memelihara benih keturunan suatu bangsa agar dapat tumbuh sehat lahir batin.
Maka perlu diperhatikan dasar jiwa yaitu keadaan jiwa yang asli menurut kodratnya sendiri, sebelum ada pengaruh dari luar; yang dibawa oleh anak-anak ketika lahir di dunia ini. Anak didik/peserta didik adalah objek sekaligus subjek pendidikan. Ki Hajar membagi tingkatan jiwa anak didik, yaitu masa kanak kanak (0 7 tahun), masa intelektual (7-14 tahun) dan masa sosial (14 21 tahun). Jadi anak didik itu manusia muda yang perlu bimbingan/pengarahan untuk mengembangkan kodratnya.

Menurut Pendidikan Islam, anak didik merupakan manusia muda yang mempunyai kemampuan/potensi yang harus dikembangkan dan diberi pengaruh yang selaras dengan ajaran Islam, sehingga nantinya anak didik akan tumbuh sebagai manusia yang berpribadi muslim. Mengenai pemikiran Ki Hajar Dewantara tentang tingkatan jwa anak adalah selaras dengan hasil pernikiran para ahli pendidikan Islam. Suatu hal yang harus diperhatikan, secara umum semua usia muslim adalah peserta didik (terdidik) sebab pendidikan Islam berlangsung seumur hidup.

Materi pendidikan. Memperhatikan konsep materi pendidikannya, selaras dengan prinsip pendidikan Islam yaitu materi pelajaran itu memberi keseimbangan bagi kehidupan anak. $\mathrm{Ki}$ Hajar menyatakan pelajaran itu 
berguna bagi perkembangan jasmani dan rohani, dan berguna bagi kehidupan anak di kemudian hari. Pelajaran itu dalam praktiknya harus memperhatikan aspek jiwa dan kemampuan anak. Artinya, bahwa materi itu tidak di luar jangkauan tingkatan jiwa kanak kanak, remaja, dan dewasa. Islam menyuruh meringankan dan tidak memberatkan atau menyusahkan. Materi yang dikemukakannya tidak kaku dan tidak rumit. la menggolongkan kepada kelompok yang mendorong pertumbuhan yang bersifat jasmaniah dan rohaniah. Hal itu secara global sejalan dengan ajaran Islam. Perbedaannya, materi pendidikan Islam harus bersumber kepada Islam.

Metoda mengajar dalam istilah Ki Hajar Dewantara disebut sebagai alat atau cara mengajar. Menurutnya banyak metoda yang bisa dipakai, namun begitu ia menjabarkan enam metoda yang pokok, yaitu pemberian contoh, pembiasaan, pengajaran, (ceramah dan lain lain), perintah laku, dan pengalaman lahir batin. Keenam metoda tersebut pada dasamya tidak keluar dari ajaran Islam.

Secara umum ia berprinsip bahwa metode itu alat, bukan tujuan. Jadi bisa berkembang sedemikian rupa sesuai kebutuhan, tapi yang perlu diperhatikan adalah hal tersebut memberi kelancaran (kalau tidak- mempermudah) guru mengajar dan murid belajar. Yang penting bagaimana mengusahakan agar tercapai perkembangan peserta didik secara optimal.

Lingkungan pendidikan menurut Ki Hajar Dewantara, pendidikan itu dapat dilaksanakan dalam tiga pusat atau tiga lingkungan hidup manusia vang disebut "Tricentra Pendidikan", yaitu keluarga, perguruan dan masyarakat. Ketiga lingkungan itu mempunyai pengaruh edukatif pada hidup tumbuhnya jiwa anak. Oleh karena itu ketiga lingkungan tersebut dapat diupayakan secara berkesinambungan menuju tujuan yang lebih tinggi, yaitu tercapainya manusia yang berkualitas dan berkepribadian. Ketiga lingkungan harus mempunyai persepsi pendidikan yang sama dan harus menjalin suatu kesatuan upaya agar anak terdidik dengan baik.

Ketiga konsep tentang lingkungan ini di dalam ajaran Islam bukan merupakan hal yang baru namun telah dicontohkan oleh nabi Muhammad saw serta diwariskan. kepada umatnya secara turun temurun. Ketiga sifat lingkungan pendidikan tersebut, memberikan pula gambaran kemungkinan mengenai bentuk bimbingan dan pengarahan kepada anak didik yang disesuaikan dengan perkembangannya. Bagi pengembangan pendidikan Islam di Indonesia, pemikiran Ki Hajar Dewantara, setidaknva memberikan satu arahan dalam menemukan tercapainya koordinasi, integrasi dan sinkronisasi agar benar benar bisa 
tercipta tiga lingkungan yang islami.

\section{(5) Prinsip Prinsip dan Strategi}

Prinsip dari konsep pendidikan Ki Hajar adalah kodrat alam, kemanusiaan, kebangsaan, kebebasan dan kemerdekaan. Masalahmasalah tersebut kajiannya telah dibuat penulis pada bagian 3 yaitu tentang tentang azas pendidikan dan tidak bertentangan dengan ajaran Islam. Strategi pendidikan merupakan suatu taktik atau siasat yang dibuat sebagai haluan dalam upaya mencapai sasaran atau tujuan.

Pertama, mengidentifikasikan dan menetapkan spesifikasi dan kualifikasi perubahan tingkah laku serta kepribadian peserta didik. Ki Hajar Dewantara mentargetkan agar pada tahap awal pendidikan dapat ditanamkan semangat perjuangan, berjiwa merdeka, berjiwa kerakyatan dan berjiwa nasional. Pengalihan konsentrasi perjuangan dari politik ke bidang pendidikan. Melalui pendidikan dengan satu perbuatan diarahkan untuk mencapai multi sasaran. Sasaran peningkatan ilmu, kesadaran, kekuatan dan kemerdekaan bangsa.

Kedua, Taman Siswa tidak secara formal dinasionalisasikan sebagai lembaga utama bagi bangsa Indonesia, namun konsep pendidikannya banyak menjadi rujukan bagi strategi pendidikan nasional di negara kita ini. Prinsip yang dikemukakannya itu sekaligus juga menunjukkan sebagai ciri falsafah yang dianut bangsa Indonesia hingga saat ini yaitu kesatuan dan persatuan berdasar Pancasila dan Undang Undang Dasar 1945 dan ini tidak bertentangan dengan ajaran Islam.

Ketiga, tahapan-tahapan proses pelaksanaan kegiatan pendidikannya selalu berjalan secara sistematis dalam arti memperhatikan ke lima unsur pokok manajemennya ialah planning, organizing, actuating, controlling dan unsur budgeting. Ia juga sebagai seorang pemimpin dan tokoh perjuangan bangsa, telah dapat menunjukkan kesuksesannya dalam memimpin. Berkenaan dengan teknologi pendidikan, konsepnya memberikan kebebasan kepada pamong atau pendidik untuk melahirkan kreasi-kreasi baru bagi pendukung keberhasilan pendidikan.

Keempat, sebelum proklamasi kemerdekaan bahasa Indonesia (Melayu) yang pernah diajukan oleh Ki Hajar agar menjadi bahasa nasional, ini menjadi kenyataan. Demikian juga dengan Taman Siswanya, tidak sedikit sumbangan berharga bagi kemajuan bangsa. Lembaga pendidikannya dikenal pula di luar negeri. Terbukti dengan banyaknya yang berkunjung kepada Ki Hajar Dewantara, seperti Dr. Rabiranath Tagore dari India, Prof Bevel dari Jeneva (Swiss), Prof Van Rees dari Amsterdam (Belanda), Prof Bousquet dari Aijazair, Dr. Navino Navaretto dari Meksiko, Prof Pandia dari 
Columbia, dan Prof Emerson dari Amerika Serikat dan banyak-lagi yang lainnya. Hemat penulis adanya hasil usaha itu sendiri konsep Pendidikan Nasional versi Ki Hajar Dewantara merupakan kekayaan berharga bagi bangsa ini dan bisa dilakukan penafsiran secara fleksibel, kritis dan dinamis.

\section{Beberapa Pandangan $\mathrm{Ki}$ Hajar Dewantara tentang Pendidikan Islam di indonesia}

Sebenarnya agak sulit untuk mengaitkan pemikiran tersebut dengan pendidikan Islam. Sebagai tokoh yang mengajukan konsep pendidikan nasional, ia tidak memaparkan secara rinci tentang pendidikan Islam. Ki Hajar Dewantara mengakui bahwa pengajaran agama Islam sebagai pengisi pengajaran adab dan kesusilaan. Sementara dalam konsep pendidikan Islam, ajaran Islam merupakan hal yang pokok dan mendasar. Dengan denikian pemikiran yang langsung disumbangkan oleh Ki Hajar Dewantara secara Islam dapat dikatakan kurang menonjol. Akan tetapi perlu diperhatikan bahwa ia sebagai seorang muslim yang dapat diklasifikasikan taat dan yang telah memunculkan konsep dan pandangan tentang pendidikan nasional.

Dijelaskankan bahwa "pemberian pengajaran agama itu sebagai etik yang bahannya bersumber dari agama. Adapun pengajaran berupa agama yang pasti (pengajaran agama Islam) diserahkan kepada pemerintah daerah". Ia menegaskan bahwa "di daerah daerah yang nyata penduduknva hidup secara adat Islam diberikan pengajaran Agama Islam, di dalam jam pengajaran, tetapi tidak dengan paksaan" (Ki Hajar, Karya ..., 1977: 88).

Dari penjelasan penjelasan tersebut, sangat jelas bahwa baik sebagai pejabat pemerintah maupun secara pribadi $\mathrm{Ki}$ Hajar Dewantara memiliki persepsi pemikiran yang positif tentang pelaksanaan pendidikan (waklu itu pengajaran) agama Islam di sekolah-sekolah negeri. Pemikiranpemikiran yang dinyatakannya itu cukup elastis dan dinamik, karena ternyata hal tersebut masih memberikan inspirasi bagi para pengambil keputusan dewasa ini. Dasar konsepnya itu dibangun dari landasan pemahaman terhadap konsep konsep agama dan aliran atau golongan agama yang berkembang yang sulit dipersatukan, sehingga ia menyerahkan hal itu kepada kebijakan politik pemerintah. Malah ia memberikan solusi pemikiran agar sekolah swasta mengambil inisiatif dan peran guna pengajaran agama itu, sebagaimana ia menegaskan dalam Kongres Pendidikan (Ki Hajar, Karya..., 1977 : 89).

Peryataan yang merupakan strategi bagi pelaksanaan pendidikan agama Islam ini bukan hanya kerangka teoritis saja, melainkan ia 
merealisasikannya secara intensif, baik pada keluarga, perguruan, maupun masyarakat. Penekanan pengajaran agama, menurutnya, lebih dalam pada keluarga dan masyarakat. Berkenaan dengan sifatnya, pelaksanaan pengajaran agama (termasuk Islam) tidak boleh dengan paksaan agar para siswa mempunyai kemerdekaan atau kebebasan memilih sehingga tidak merasa ditekan. Adapun materi pengajaran itu, baik (di keluarga, masyarakat, atau sekolah), ia mengajukan pendapatnya agar tidak fikih sentris, tetapi ajaran secara keseluruhan. Masalahnya, bisa timbul dikotomi dalam dunia pendidikan, $\mathrm{khu}$ susnya mengenai pelajaran. $\mathrm{Di}$ kalangan Islam tidak kurang dari sederetan tokoh tokoh pendidikan Islam terus menerus mencari solusi bagi kerancuan pemikiran tersebut, termasuk di Indonesia.

Hubungannya dengan lembaga pendidikan Islam, ia memuji sistem asrama, madrasah, pondok pesantren, dan sekolah tradisional lainnya yang telah aktif memajukan bangsa. Penghargaan Ki Hajar terhadap sistem pendidikan tradisional, kontras dengan pandangan pergerakan nasional yang tampak pada Budi Utomo. Ki Hajar mengalami penggodogan keluarga muslim dan pernah mengikuti sistem pendidikan Barat, serta orang pertama yang membuat konsep jalan tengah antara Barat dan Timur dalam dunia pendidikan.

\section{E. Kesimpulan dan Saran}

Setelah penulis menginventarisasikan hasil temuan tentang $\mathrm{Ki}$ Hajar Dewantara dan konsep pendidikannya yang dianalisis berdasarkan pandangan Islam, maka dapat ditarik kesimpulan berikut ini:

Ki Hajar Dewantara yang lahir di Yogyakarta tanggal 2 Mei 1889 adalah seorang tokoh yang memiliki perilaku keagamaan (Islam) yang taat, baik dilihat dari aspek keimanan, peribadatan, maupun akhlaknya. Ia telah dapat memoderasi antara kemoderenan dan keindonesiaan. Ia tergolong tokoh kebangkitan/pembaharuan bagi bangsa Indonesia, sejalan dengan tokoh kebangkitan/pembaharuan Islam lainnya seperti Moh. Iqbal, Sayyid Ahmad Khan, dan Ali Mubarok.

Dipandang dari segi ajaran Islam, keberadaan konsep pendidikan nasional Ki Hajar Dewantara secara umum tidak bertentangan, bahkan banyak yang relevan dengan konsep pendidikan Islam. Berkenaan dengan asas pendidikan yaitu Pancadarma yang meliputi kemerdekaan, kodrat alam, kebudayaan, kebangsaan dan kemanusiaan, sejalan dengan ajaran Islam. Perbedaan yang nyata ialah bahwa pendidikan Islam adalah pendidikan yang berasaskan Islam. Sedangkan di sini ia tidak menyebut kata Islam secara tekstual. Demikian halnya dengan 
tujuan pendidikannya, walaupun Ki Hajar Dewantara secara tekstual tidak menyebut muslim atau Islam sebagai sasaran, secara kontekstual tujuan tersebut tidak bertentangan, bahkan sejalan dengan tujuan pendidikan Islam.

Keberadaan komponen proses pendidikan nasional Ki Hajar Dewantara dipandang dari segi ajaran Islam adalah sejalan. Mengenai anak didik, tidak tampak adanya perbedaan-perbedaan yang prinsipil, baik dilihat dari segi manusia sebagai individu, sebagai anggota masyarakat, maupun sebagai warga dari suatu negara. Berkenaan dengan pendidik, baik dilihat dari aspek fungsinya, tugas/ kewajiban, kompetensi dan profesionalisasinya, dapat disimpulkan bahwa walaupun tidak sama persis, tidak bertentangan dengan kriteria pendidik dalam Islam. Perbedaan yang tampak ialah pada syarat dan sikap yang harus dimiliki oleh pendidik dalam Islam, yakni harus beragama Islam, harus mempunyai sifat dan sikap yang islami.

Demikian halnya dalam unsur materi pelajaran, metoda mengajar dan lingkungan belajar (pendidikan), secara umum tidak bertentangan dengan konsep pendidikan dalam Islam. Dalam masalah materi, misalnya, cukup fleksibel yaitu mata pelajaran yang dibutuhkan bagi perkembangan jasmani dan rohani. Dalam masalah metoda, enam macam yang diajukan dalam konsepnya itu semua tidak berten- tangan bahkan sejalan dengan metoda pendidikan Islam. Berkenaan dengan masalah lingkungan pendidikan, Islam sangat mendambakan terciptanya keterpaduan ketiga lingkungan yang islami. Demikian juga Ki Hajar Dewantara menekankan agar hubungan antara keluarga, sekolah, dan masyarakat dapat terjalin secara terpadu dan terarah. Dan ia juga memuji sistem pondok/ asrama seperti halnya di pondok pesantren.

Adapun mengenai prinsipprinsip konsep pendidikan nasional Ki Hajar Dewantara tidak ditemukan rincian secara khusus. Namun, Pancadarma itu selain sebagai asas, juga merupakan prinsip dari konsepnya. Hal itu tidak bertentangan sebagaimana telah diterangkan. Adapun strategi yang diterapkan Ki Hajar Dewantara dalam rangka memasyarakatkan konsepnya itu tidak melangggar aturan/ajaran agama. Misalnya, dalam rangka mencerdaskan bangsa, penyadaran rasa kebangsaan, pembinaan kepribadian, sebagai pranata tandingan sistem pendidikan ekstra kolonial. Strategi itu sejalan, bahkan juga menjadi cita-cita umat Islam saat itu yang mendambakan kemerdekaan. Berkaitan dengan penyelenggaraan pendidikan agama di Indonesia, Ki Hajar Dewantara telah secara positif menghargai lembaga-lembaga pendidikan partikelir yang umumnya didirikan 
oleh yayasan/organisasi Islam atau perorangan, baik pondok pesantren, madrasah, dan sekolahsekolah. Pandangannya tentang pendidikan agama sebagai mata pelajaran di sekolah-sekolah, tidak terkonsepsikan secara detail seperti pendidikan nasional. Namun, ia secara positif memberikan tonggak dasar, minimal sebagai suatu sinyalemen konsep bagi pendidikan agama/keagamaan (Islam) di Indonesia. Di samping telah menampilkan konsep pendidikan secara umum, ia juga telah mengemukakan pemikirannya tentang konsep pendidikan budi pekerti yang identik dengan bidang pendidikan akhlak dalam Islam.

Berdasarkan kesimpulan tersebut, maka penulis menyarankan: pertama, ditujukan kepada pengurus besar majelis luhur Taman Siswa untuk menambah secara tekstual rujukan tentang keimanan dan ketakwaan terhadap Tuhan yang maha esa dalam pancadarma, misalnya dengan menambah kalimat ketuhanan yang maha esa dalam tanda kurung sehingga tampak secara tektual dan dapat dipahami.

Kedua, ditujukan kepada pemerintah dan aparatur terkait dalam lembaga-lembaga serta perorangan yang kompeten berkenaan dengan masalah berikut:

\section{Dikotomi antara Pendidikan} Agama dan Pendidikan Umum
Temuan penulis menunjukan tidak kurang dari para ulama besar, tokoh-tokoh pembaharuan dan para intelektual muslim sependapat bahwa adanya dikotomi tersebut melahirkan sedikit manfaat dibanding madaratnya. Oleh karena itu, dipandang perlu untuk dibenahi/diupayakan berangsurangsur hapusnya hal tersebut, terutama di negara-negara Islam/ mayoritas penduduknya beragama Islam.

\section{Moralitas bangsa}

Tipis kemungkinan adanya kontradiktif jika memperhatikan konsep Ki Hajar Dewantara yang mewajibkan pendidikan budi pekerti bagi para pemuda/remaja, termasuk anak anak sekolah, bahkan meningkatkannya kepada pendidikan adab agar bangsa ini benar benar berkeadaban. Jika semua atau sebagian besar siswanya beragama Islam, maka diberikan pendidikan akhlak karena menurut Ki Hajar pendidikan budi pekerti bersumber dari agama.

\section{Pondok Pesantren dan Madrasah Diniyah}

Ki Hajar Dewantara tidak meragukan eksistensi dan fungsi lembaga ini, bahkan sebagai suatu lembaga yang perlu diperpesat. Demikian juga temuan para peneliti telah dapat mengungkapkan peran lembaga ini sebelum maupun sesudah kemerdekaan. 
Mengingat pertumbuhan pondok pesantren dan madrasah diniyah dewasa ini sudah hampir merata di seluruh pelosok tanah air sehingga telah berfungsi sebagai media dan sarana komunikasi pembangunan bangsa. Oleh karena itu, sewajarnya diberikan perhatian dan penanganan khusus dalam pengelolaannya. Sebaliknya, para pengelola pondok pesantren dan madrasah diniyah sendiri seyogyanya untuk melakukan revitalisasi agar kontribusi yang telah diberikan kepada bangsa ini lebih meningkat dan dirasa tepat sesuai dengan sifatnya yaitu untuk kemaslahatan umat.[]

\section{DAFTAR PUSTAKA}

Ahmad, Kursid, Prinsiple of Islamic Education (Prinsip prinsip Pendidikan (slam), terj, As. Robith, Progressif, Surabaya, 1992

Alatas, Naquib, The Concept of Education in Islam (Konsep Pendidikan dalam (slam), terj. Haidar Bagir, Mizan, Bandung, 1992

Al Abrasy, Athiyah M., Al Tarbiyah al Islamiyah, (Pendidikan Islam), terj. Bustami A. Ghani, Bulan Bintang, Jakarta, 1993

Al Bagdadi, Abdu al Rahman, $A l$ Tarbiyah (Pendidikan di masa
Khalifah Islam), terj. Nur Eva, Al Izzah, Bangil, 1996

Al Jamali, Fadil, Menerobos Krisis Pendidikan Dunia Islam, terj. Muzayyin Arifin, Golden Trayon Press, Jakarta, 1988

Al Nahlawi, Abu al Rahman, Ushulu al Tarbiyah al Islamiyah wa As Libuha (Prinsip prinsip dan Metode Pendidikan1slam), terj. Hary Noor Ali, Diponegoro, Bandung, 1992

Asraf Ali, Sayyid, New Horison in Muslim Education (Horizon Baru Pendidikan Islam) terj. S. Siregar, Firdaus, Jakarta, 1989

Azra, Azyumardi, Esai Esai Intelektual Muslim dan Pendidikan Islam, Logos, Wacana IImu, Jakarta, 1999

Bayard, Dodge, Muslim Education in Mediieval Times, (Washington, The Middle East Institutie, 1962)

Beeby, C.E. Assesment of Indonesian Education (Pendidikan di Indonesia), terj. BP3K \& YIIS LP3s, Jakarta, 1991

Daradjat, Zakiah, Ilmu Pendidikan IsIam, Bumi Aksara, Jakarta, 1991

Dewantara, KI Hajar, Teks Pidato Berdirinya Taman Siswa, Dok. Majlis Luhur Taman siswa, Yogyakarta, 1922 Konsepsi Pendidikan Nasional, Majlis Luhur Taman Siswa, Yogyakarta, 1922 Puncak puncak dan 
Sari Kebudayaan Nasional, Majlis Luhur Taman Siswa, Yogyakarta, 1952

\section{Dari Kebangunan}

Nasional Sampai Proklamasi Kemerdekaan, CV. Pustaka, Penerbit Endang, Jakarta, 1952 Teks Pidato

Penganugerahan Gelar Doktor dalam Kebudayaan, dari Universitas Gajah Mada, Dok. Majlis Luhur Taman Siswa, Yogyakarta, 1957

Demokrasi dan

Leideirschap, Majlis Luhur Taman Siswa, Yogyakarta, 1959 Karya I (Pendidikan),

Majlis Luhur Taman Siswa, Yogyakarta, 1962 Karya II (Kebudayaan), Majlis Luhur Taman Siswa, Yogyakarta, 1967

Surat surat Kepada Keluarga dan Kepada Kawan kawan Seperjuangan, Dok. Majlis Luhur Taman Siswa, Yogyakarta

Dewantara, Bambang Sukowati, $K i$ Hajar Dewuantara, Roda Pengetahuan, Jakarta, 1981

Haryadi, Sepuluh Talun Pengembangan Taman Siswa, 1972 1982, Majlis Luhur Taman Siswa, Yogyakarta, 1982
Kafrawi, HM., Pembaharuan Sistem Pendidikan Pondok Pesantren, Cemara Indah, Jakarta, 1978

Langgulung, Hasan, Azas azas Pendidikan Islam, Al Husna, Jakarta, 1987

Pranata, Ki Hajar Dewantara, Balai Pustaka, Jakarta, 1987

Suratman, Darsiti, Ki Hajar Dewantara, Depdikbud., Jakarta, 1985

Stenbrink, Karl., Pesantren, Madrasah dan Sekolah, LP3ES., Jakarta, 1986

Suminto, Aqib, Politik Islam Hindia Belanda, LP3ES., Jakarta

Suryomiharjo, Abdu Al Rahman, Ki Hajar Dewantara dan Taman Siswa dalam Sejarah Indonesia Modern), Sinar Harapan, Jakarta, 1986

Tauchid, Muhammad, Perjuangan Ki Hajar Dewantara, Majlis Luhur Taman Siswa, Yogyakarta, 1973

Yunus, Mahmud, Sejarah Pendidikan Islam di Indonesia, Hida Karya Agung, Jakarta, 1985

Zuhairini, dkk., Sejarah Pendidikan Islam, Bina Aksara, Jakarta, 1992 